\title{
Dominant-Negative Calcium Channel Suppression by Truncated Constructs Involves a Kinase Implicated in the Unfolded Protein Response
}

\author{
Karen M. Page, ${ }^{\star}$ Fay Heblich, ${ }^{\star}$ Anthony Davies, ${ }^{\star}$ Adrian J. Butcher, ${ }^{\star}$ Jerôme Leroy, Federica Bertaso, Wendy S. Pratt, \\ and Annette C. Dolphin \\ Department of Pharmacology, University College London, London WC1E 6BT, United Kingdom
}

\begin{abstract}
Expression of the calcium channel $\mathrm{Ca}_{\mathrm{v}} 2.2$ is markedly suppressed by coexpression with truncated constructs of $\mathrm{Ca}_{\mathrm{v}} 2.2$. Furthermore, a two-domain construct of $\mathrm{Ca}_{\mathrm{v}} 2.1$ mimicking an episodic ataxia-2 mutation strongly inhibited $\mathrm{Ca}_{\mathrm{v}} 2.1$ currents. We have now determined the specificity of this effect, identified a potential mechanism, and have shown that such constructs also inhibit endogenous calcium currents when transfected into neuronal cell lines. Suppression of calcium channel expression requires interaction between truncated and full-length channels, because there is inter-subfamily specificity. Although there is marked cross-suppression within the $\mathrm{Ca}_{\mathrm{V}} 2$ calcium channel family, there is no cross-suppression between $\mathrm{Ca}_{\mathrm{v}} 2$ and $\mathrm{Ca}_{\mathrm{v}} 3$ channels. The mechanism involves activation of a component of the unfolded protein response, the endoplasmic reticulum resident RNA-dependent kinase (PERK), because it is inhibited by expression of dominant-negative constructs of this kinase. Activation of PERK has been shown previously to cause translational arrest, which has the potential to result in a generalized effect on protein synthesis. In agreement with this, coexpression of the truncated domain I of $\mathrm{Ca}_{\mathrm{v}} 2.2$, together with full-length $\mathrm{Ca}_{\mathrm{v}} 2.2$, reduced the level not only of $\mathrm{Ca}_{\mathrm{v}} 2.2$ protein but also the coexpressed $\alpha 2 \delta-2$. Thapsigargin, which globally activates the unfolded protein response, very markedly suppressed $\mathrm{Ca}_{\mathrm{v}} 2.2$ currents and also reduced the expression level of both $\mathrm{Ca}_{\mathrm{V}} 2.2$ and $\alpha 2 \delta$-2 protein. We propose that voltage-gated calcium channels represent a class of difficult-to-fold transmembrane proteins, in this case misfolding is induced by interaction with a truncated cognate $\mathrm{Ca}_{\mathrm{V}}$ channel. This may represent a mechanism of pathology in episodic ataxia-2.
\end{abstract}

Key words: calcium channel; current; suppression; episodic ataxia-2; truncation; aggregation

\section{Introduction}

Voltage-gated calcium channels serve a number of vital functions, including neurotransmitter release and muscle contraction (for review, see Catterall, 2000). They are heteromeric complexes consisting of the pore-forming $\mathrm{Ca}_{\mathrm{V}} \alpha 1$ subunit together (except in the case of the $\mathrm{Ca}_{\mathrm{v}} 3$ channels) with an accessory $\beta$ and $\alpha 2-\delta$ subunit. The $\mathrm{Ca}_{\mathrm{V}} \alpha 1$ subunit consists of four homologous domains (I-IV), each containing six transmembrane (TM) segments, linked by intracellular loops and with intracellular $\mathrm{N}$ and $\mathrm{C}$ termini. There are $10 \alpha 1$ subunits divided into three subfamilies, $\mathrm{Ca}_{\mathrm{V}} 1-3$ (Ertel et al., 2000).

Expression of two-domain isoforms of voltage-gated cation channels including $\mathrm{Ca}_{\mathrm{V}} 1.1, \mathrm{Ca}_{\mathrm{V}} 1.2$, and the $\mathrm{Na}^{+}$channel SCN8A has been found to occur in a number of tissues, in some cases in a

\footnotetext{
Received Feb. 17, 2004; revised May 3, 2004; accepted May 3, 2004.

This work was supported by the Wellcome Trust and the Medical Research Council. We thank the following for CDNAs: Dr. E. Perez-Reyes (Cav 3.1, Ca $\mathrm{C}_{\mathrm{v}} 3.2, \beta 1 \mathrm{~b}$, and $\left.\beta 4\right)$, Dr. L. Kaczmarek (Kv $\left.3.1 \mathrm{~b}\right)$, Dr. Y. Mori (Ca 2 2.1 and $\left.\mathrm{Ca}_{\mathrm{v}} 2.2\right)$, Dr. D. Ron (PERK constructs), and Dr. A. Tinker (Kir2.1-AAA). We also thank T. Shafer and D. Cox for PC12 cells and K. Chaggar and J. Wratten for technical assistance.

*K.M.P., F.H., A.D., and A.J.B. contributed equally to this work.

Correspondence should be addressed to Dr. A. C. Dolphin, Department of Pharmacology, University College London, Gower Street, London WC1E 6BT, UK. E-mail: a.dolphin@ucl.ac.uk.

DOI:10.1523/JNEUROSCI.0553-04.2004

Copyright $\odot 2004$ Society for Neuroscience $\quad$ 0270-6474/04/245400-10\$15.00/0
}

developmentally regulated manner (Plummer et al., 1997; Wielowieyski et al., 2001; Okagaki et al., 2001; Ahern et al., 2001; Arikkath et al., 2002). Furthermore, mutations that result in truncations of calcium channel $\alpha 1$ subunits can contribute to a number of pathological states. For example, in episodic ataxia type-2 (EA2), mutations in $\mathrm{Ca}_{\mathrm{v}} 2.1$ predict truncated forms of this channel (Ophoff et al., 1996; Denier et al., 1999).

In our initial study on truncated $\mathrm{Ca}_{\mathrm{V}} \alpha 1$ subunits, we showed that truncated constructs containing the first one or two domains of $\mathrm{Ca}_{\mathrm{V}} 2.2$ suppressed $\mathrm{Ca}_{\mathrm{V}} 2.2$ currents and reduced full-length $\mathrm{Ca}_{\mathrm{V}} 2.2$ protein (Raghib et al., 2001). Here, we have deduced a potential mechanism that also relates to a two-domain truncated $\mathrm{Ca}_{\mathrm{V}} 2.1$ construct predicted by an EA2 mutation and have extended the finding to native calcium channels in neuronal cell lines. Our results suggest that suppression requires interaction between a truncated construct and a related full-length channel, which activates a component of the unfolded protein response (UPR) to suppress translation.

The UPR is initiated when the endoplasmic reticulum (ER) lumen is unable to cope with the load of newly synthesized proteins requiring folding (for review, see Harding et al., 2002). An early consequence is translation inhibition mediated by an ERresident RNA-dependent protein kinase (PERK). This is a trans-ER membrane protein with a cytoplasmic kinase domain 
and an ER lumenal domain that is activated by unfolded proteins in the ER (Harding et al., 1999). PERK phosphorylates the ribosomal translation initiation factor $\operatorname{eIF} 2 \alpha$ and in this way suppresses translation. In addition, there are other pathways activated by the UPR (Mori, 2000; Liu and Kaufman, 2003). Furthermore, it has been found recently that the various pathways may also be activated separately, transiently, and with differential timing (for review, see Rutkowski and Kaufman, 2004).

The activation of PERK is designed to protect cells during short-term stress (Mori, 2000; Harding et al., 2002). However, if ER stress is prolonged, it will lead to cell death. With respect to its involvement in neuropathology, the UPR has been implicated in cellular models of Parkinson's disease (Ryu et al., 2002) and in neurodegeneration of the nigrostriatal tract in a familial form of Parkinson's disease involving mutations in the proteasomal pathway (Imai et al., 2001). Our results suggest that it may also play a role in the pathophysiology of EA2.

\section{Materials and Methods}

Materials. The following cDNAs were used: $\mathrm{Ca}_{\mathrm{v}} 2.2$ [D14157 without 3' untranslated region (UTR)], $\mathrm{Ca}_{\mathrm{V}} 2.1$ [M64373 with E1686R mutation (Brodbeck et al., 2002)], Ca 2.3 (RbEII, L15453), Ca 3 3.1 (AF027984), $\mathrm{Ca}_{\mathrm{V}} 1.2$ (M67515), $\alpha 2 \delta$-1 (M86621), $\alpha 2 \delta$-2 (Barclay et al., 2001), $\beta 1 \mathrm{~b}$ (Tomlinson et al., 1993), $\beta 4$ (M80545), Kir2.1-AAA (Tinker et al., 1996), and green fluorescent protein (GFP) mut3b (Cormack et al., 1996) in pMT2. PERK, PERK K618A, and PERK $\Delta$ C terminus constructs were used in pcDNA1 (Harding et al., 1999). $\mathrm{K}_{\mathrm{V}} 3.1 \mathrm{~b}$ (M68880) was in pRCCMV and $\mathrm{Ca}_{\mathrm{V}} 3.2$ (AF051946) in pRK5.

Truncated and chimeric $\mathrm{Ca}_{v}$ constructs. Constructs were made by standard techniques and verified by automated sequencing. The $\mathrm{Ca}_{\mathrm{v}} 2.2-$ Dom I, Ca $a_{\mathrm{V}}$ 2.2-Dom I-II, and GFP-Ca $2.2-$ Dom I-II constructs have been described previously (Raghib et al., 2001). Other constructs used were $\mathrm{Ca}_{\mathrm{V}}$ 2.2-Dom I H6 [residues 1-483 plus a C-terminal His(6) tag], $\mathrm{Ca}_{\mathrm{V}} 3.1$ containing a C-terminal Myc and $\mathrm{His}(10)$ tag, $\mathrm{Ca}_{\mathrm{V}} 2.1-\mathrm{P} 1217 \mathrm{fs}$ [residues 1-1216 with 27 additional amino acids attributable to the frame shift (fs)], Ca 3 3.1-Dom I [residues 1-743, plus a C-terminal His(6) tag], $\mathrm{Ca}_{\mathrm{V}}$ 3.1-Dom I-II (residues 1-1253), and $\mathrm{Ca}_{\mathrm{V}} 3.2-\mathrm{Dom} \mathrm{I}$ (residues 1-791). The tags were used for Western blotting to confirm expression.

Cell culture and heterologous expression. COS-7 cells were cultured as described previously (Campbell et al., 1995). The tsA-201 cells were cultured in a medium consisting of MEM, 10\% FBS, and 1\% nonessential amino acids. NG108-15 cells were cultured as described (Robbins et al., 1993). PC12 cells were grown in DMEM, 7.5\% FBS, and 7.5\% horse serum. Cells were transfected using either Geneporter (Qbiogene, Harefield, UK) or Fugene (Roche Diagnostics, Mannheim, Germany), with equivalent results. The cDNAs (all at $1 \mu \mathrm{g} \cdot \mu \mathrm{l}^{-1}$ ) for $\mathrm{Ca}_{\mathrm{V}} \alpha 1$ subunits, truncated domain constructs, $\alpha 2 \delta-1$ or $\alpha 2 \delta-2, \beta 1 \mathrm{~b}$, and GFP when used as a reporter of transfected cells were mixed in a ratio of 3:1.5:2:1: 0.2 , unless stated otherwise. When particular subunits were not used, the volume was made up with water, or blank vector, or the volume of transfection reagent was reduced, with equivalent results. PC12 cells were transfected using $4 \mu \mathrm{l}$ of cDNAs for GFP or GFP-Ca $\mathrm{V}_{\mathrm{V}} 2.2$-Dom I-II and Fugene. Differentiation was with serum-free medium containing NGF (100 ng/ml murine 7s NGF; Invitrogen, Carlsbad, CA), replenished every $48 \mathrm{hr}$. Cells were used for recording after 5-7 d of differentiation.

Xenopus oocytes were prepared, injected, and used for electrophysiology as described previously (Canti et al., 1999), with the following exceptions. Plasmid cDNAs for the different calcium channel subunits $\alpha 1$, $\alpha 2 \delta-2$, and $\beta 1 \mathrm{~b}$ and truncated domains and other constructs were mixed in equivalent weight ratios at $1 \mu \mathrm{g} \cdot \mu \mathrm{l}^{-1}$, unless stated otherwise, and $9 \mathrm{nl}$ was injected intranuclearly. The corresponding mRNAs were made by mMessage mMachine (Ambion, Austin, TX), diluted to $0.5 \mu \mathrm{g} \cdot \mu \mathrm{l}^{-1}$, mixed in a ratio $3: 1: 1: 3$, and $60 \mathrm{nl}$ was injected intracytoplasmically. For quantitative reverse transcription-PCR (QPCR), plasmid cDNAs for $\mathrm{Ca}_{\mathrm{v}} 2.2, \beta 1 \mathrm{~b}, \alpha 2 \delta$-2, Kir2.1-AAA plus $\mathrm{Ca}_{\mathrm{v}} 2.2$-Dom I, or blank vector were injected intranuclearly into oocytes in the ratio $6: 2: 2: 1: 3$, unless stated otherwise. After $\sim 48 \mathrm{hr}$, individual oocytes were harvested and RNA was isolated using RNeasy columns (Qiagen, Hilden, Germany), including an on-column DNase step.

Identification of a PERK gene product in Xenopus oocytes. Primers were designed by aligning Xenopus expressed sequence tag (EST) sequences (BU914407, BF427225, BI445972, BU912964, and CA791610) with mouse PERK (AF076681). The primers 5'-AGTCTCTGCTGGAGTCTTCA and 5'-TGACACTGTGTCTCAGACTCTT generated a 1145 bp product. The novel sequence represented by part of this PCR product was submitted to GenBank (accession number AY512645). Translation of this PCR product, combined with the EST sequences BU911407 and BI445972, gave a fragment of 425 aa. A second PCR product generated using the primers $5^{\prime}$ GTCGCGGTACCTCACAGATT and 5'-CACAGCTGCATCTGGATGTA gave a 921 bp product. The sequence of this confirms the EST BU912964.

Measurement of mRNA levels by QPCR. Reverse transcription was performed using random hexamer primers and Moloney murine leukemia virus reverse transcriptase (Promega, Madison, WI) at $37^{\circ} \mathrm{C}$ for $2 \mathrm{hr}$. QPCR was performed with an iCycler (Bio-Rad, Hercules, CA) using the iQ SYBR supermix. For each set of primers and for every experiment, a standard curve was generated using a serial dilution of reverse-transcribed RNA combined from several oocytes. The following primers were used: $\mathrm{Ca}_{\mathrm{v}} 2.2$, 5'-CTCTGCGCTTACTGAGAATC and 5'-AACAGGAAGAGCAGGAAGAG; Kir2.1-AAA, 5'-TGGGTGAGAAGGGACAGAGGTA and 5'-AGGAGAGCACGAAGGCAAGAC; 18S，5'-TGACTCAACACGGGAAACCT and 5' -AATCGCTCCACCAACTAAGAAC; PERK, 5' -GGACCAAGAAGAAGATGAAGAA and 5'-CTGTGTGCTGAATGGGTATAA. Data were analyzed using REST software (Pfaffl et al., 2002) and normalized for expression of $18 \mathrm{~S}$ ribosomal RNA.

Western blotting and calcium channel subunit quantification. COS-7 cells were processed for SDS-PAGE as described (Raghib et al., 2001). Western blotting of individual oocytes was performed as described (Canti et al., 2001). Individual oocytes were lysed, solubilized, centrifuged $(10,000 \times g, 5 \mathrm{~min})$, and the supernatants were assayed for total protein content as described (Canti et al., 2001). Samples (50 or $30 \mu \mathrm{g}$ of cell lysate protein/lane for COS-7 cells and oocytes, respectively) were separated using Novex $4-12 \%$ Tris-glycine or $4-12 \%$ Bis-Tris NuPAGE gels (Invitrogen) and transferred electrophoretically to polyvinylidene fluoride membranes. The membranes were blocked with 3\% BSA $/ 0.02 \%$ Tween 20 and then incubated overnight at room temperature with the relevant primary antibody: 1:1000 dilution of anti-Ca 2.2 (Raghib et al., 2001 ), protein A IgG cut from anti- $\beta 1$ b serum (Moss et al., 2002) used at $10 \mu \mathrm{g} / \mathrm{ml}$, anti- $\alpha 2 \delta-2 \mathrm{Ab} 102-117$ used at $1 \mu \mathrm{g} / \mathrm{ml}$ (Brodbeck et al., 2002), 1:1000 dilution of His-probe Ab (Santa Cruz Biotechnology, Santa Cruz, CA), or 1:1000 dilution of c-myc 9E10 Ab (Santa Cruz Biotechnology). Detection was performed either with a 1:1000 dilution of goat anti-rabbit (or anti-mouse) IgG-HRP conjugate (Bio-Rad Laboratories, Richmond, CA) and ECLplus (Amersham Biosciences (Amersham Biosciences), Little Chalfont, UK), or with a 1:1000 dilution of goat anti-rabbit IgG-Cy5 conjugate (Amersham Biosciences), all in conjunction with a Typhoon 9410 Variable Mode Imager (Amersham Biosciences), set in chemiluminescence or fluorescence mode, respectively. Protein bands were quantified using Imagequant version 5.2.

Electrophysiology. Whole-cell patch-clamp recording was performed and analyzed as described (Meir et al., 2000), with 1-20 $\mathrm{mM} \mathrm{Ba}^{2+}$ as charge carrier (as stated) and a holding potential of $-100 \mathrm{mV}$. Currents were measured $10 \mathrm{msec}$ after the onset of the test pulse, and the average over a $2 \mathrm{msec}$ period was calculated and used for analysis. Xenopus oocyte recordings were performed as described (Canti et al., 2001). The holding currents at $-100 \mathrm{mV}$ were stable and usually in the range -50 to -100 $\mathrm{nA}$. The $\mathrm{Ba}^{2+}$ concentration was $5 \mathrm{~mm}$, unless stated otherwise. Data are expressed as means $\pm \mathrm{SEM}$, and $I-V$ plots were fit with a modified Boltzmann equation as described (Canti et al., 2001). $\mathrm{K}^{+}$currents were recorded as described (Moss et al., 2002). When used, thapsigargin (Sigma, St. Louis, MO) was dissolved in DMSO at $1 \mathrm{~mm}$. Xenopus oocytes were incubated with thapsigargin $(1 \mu \mathrm{M})$ or the equivalent amount of DMSO as control, from $12 \mathrm{hr}$ after cDNA injection to the time of $\mathrm{Ca}_{\mathrm{V}} 2.2$ recording $(\sim 48 \mathrm{hr})$. 

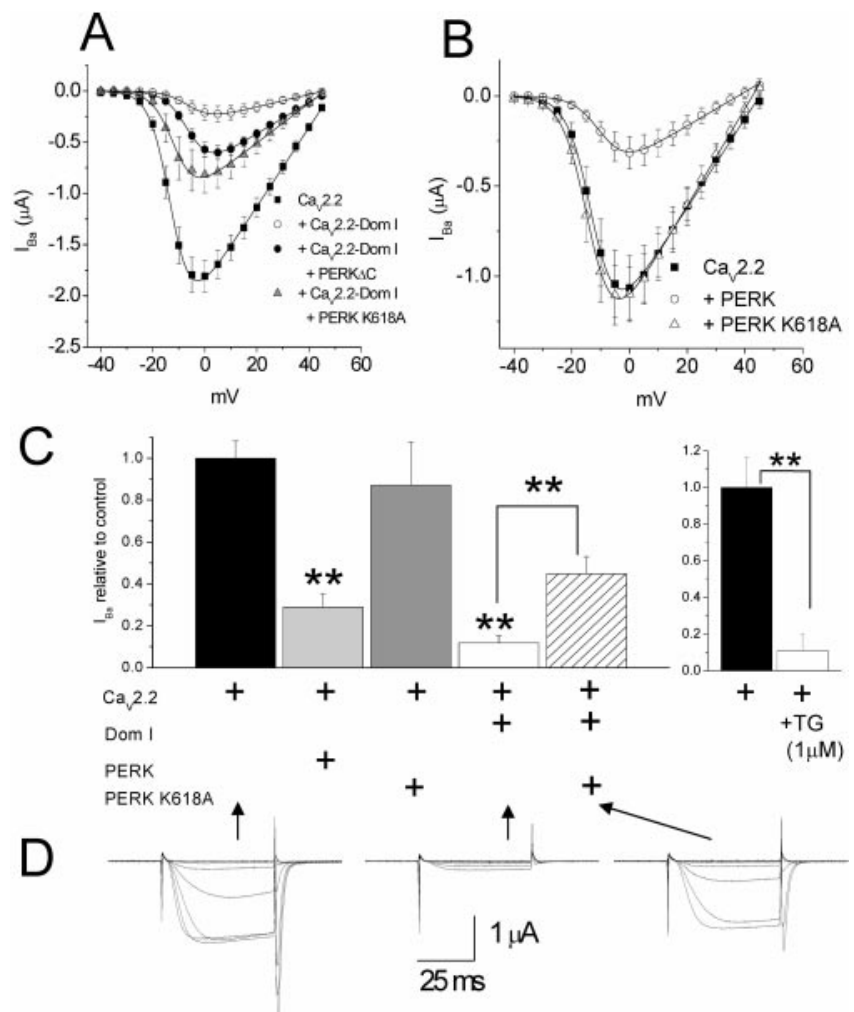

Figure 1. The effect of PERK and dominant-negative PERK constructs on suppression of $\mathrm{Ca}_{\mathrm{v}} 2.2 \mathrm{I}_{\mathrm{Ba}}$ by $\mathrm{Ca}_{\mathrm{v}} 2.2-\mathrm{Dom}$ I. $A, \mathrm{Ca}_{\mathrm{v}} 2.2 / \alpha 2 \delta-2 / \beta 1 \mathrm{~b} \mathrm{~B}_{\mathrm{Ba}}$ recorded in Xenopus oocytes, either in the absence $(\square ; n=29)$ or presence of $\left(\mathrm{C}_{\mathrm{v}} 2.2-\mathrm{Dom} \mathrm{I}(\mathrm{O} ; n=19), \mathrm{C}_{\mathrm{v}} 2.2\right.$-Dom I plus PERK K618A $(\triangle ; n=24)$, or $C a_{\mathrm{v}} 2.2-$ Dom I plus PERK $\Delta C(\mathbf{O} ; n=18)$. The mean $I-V$ plots gave maximum conductance $\left(G_{\max }\right)$ values of $38.6,6.1,19.4$, and $15.4 \mu$ S, respectively. $B, C_{a} 2.2 / \alpha 2 \delta-2 / \beta 1 \mathrm{~b}$ $\mathrm{I}_{\mathrm{Ba}}$ recorded in the same experiments either in the absence $(\boldsymbol{\square} ; n=20)$ or presence of PERK $(O$; $n=15)$ or PERK K618A $(\triangle ; n=26)$. The mean $I-V$ plots gave $G_{\text {max }}$ values of $24.7,9.4$, and 27.0 $\mu$ S, respectively. C, Left, Histogram of all mean data obtained at $0 \mathrm{mV}$ for control $\mathrm{Ca}_{\mathrm{y}} 2.2 / \beta 1 \mathrm{~b} /$ $\alpha 2 \delta$-2 I $\mathrm{Ba}(\square ; n=35)$ in the presence of PERK ( $\square ; n=24)$, PERK K618A ( $\square ; n=26)$, Ca 2.2-Dom I ( $\square ; n=26$ ) or Ca 2.2-Dom I plus PERK K618A ( (ש2; $n=27)$. Right, Effect of incubation of oocytes with thapsigargin ( $\mathrm{TG} ; 1 \mu \mathrm{M} ; n=3 ; \square$ ) compared with control (incubated with the same concentration of DMSO; $\mathbf{\square} ; n=10)$. Only 3 of 10 thapsigargin-treated oocytes showed any current compared with 10 of 11 control oocytes that expressed $\mathrm{Ca}_{\mathrm{v}} 2.2$ currents in the same experiment. The mean peak $I_{B a}$ at $0 \mathrm{mV}$ is expressed relative to control. Statistical significance compared with control or $\mathrm{Ca}_{\mathrm{v}} 2.2-\mathrm{Dom}$ I where indicated: ${ }^{* *} p<0.001$. $D$, Examples of $\mathrm{B}_{\mathrm{Ba}}$ : left, $\mathrm{Ca}_{\mathrm{v}} 2.2 / \beta 1 \mathrm{~b} / \alpha 2 \delta$-2; center, plus $\mathrm{Ca}_{\mathrm{v}} 2.2$-Dom I; right, plus $\mathrm{Ca}_{\mathrm{v}} 2.2$-Dom I and PERK K618A. The calibration bar refers to all panels. $I_{B a}$ is shown in $5 \mathrm{mV}$ steps between -40 and $0 \mathrm{mV}$.

\section{Results}

The first set of experiments was performed in Xenopus oocytes because the amount and proportions of different cDNAs received by each oocyte can be accurately controlled, and biochemical studies can be performed on the individual oocytes from which recordings were made, without the factor of transfection efficiency that may confound the comparison of electrophysiological and biochemical data when using transient transfection of mammalian cells. We first confirmed that the suppression of $\mathrm{Ca}_{\mathrm{V}} 2.2$ currents by truncated $\mathrm{Ca}_{\mathrm{V}} 2.2$ constructs also occurred in this system. The $\mathrm{Ca}_{\mathrm{V}} 2.2$-Dom I produced almost $90 \%$ suppression of $\mathrm{Ca}_{\mathrm{V}} 2.2$ currents in Xenopus oocytes (Fig. 1 A, C; Table 1), with no significant effect on steady-state inactivation (data not shown). Two controls were performed. First, coexpression of $\mathrm{Ca}_{\mathrm{V}} 2.2$ channels with a control nonfunctional membrane protein, a mutant Kir2.1 construct that has a mutated pore signature sequence $(\mathrm{GYG} \rightarrow \mathrm{AAA})$ rendering it nonconducting (Tinker et al., 1996), produced no inhibition of $\mathrm{Ca}_{\mathrm{V}} 2.2$ barium current $\left(\mathrm{I}_{\mathrm{Ba}}\right)$ (Table 1). Second, coexpression of $\mathrm{Ca}_{\mathrm{V}}$ 2.2-Dom I with another voltagegated channel, $\mathrm{K}_{\mathrm{V}} 3.1 \mathrm{~b}$, produced no significant inhibition of this $\mathrm{K}^{+}$current (data not shown).

\section{Does suppression by truncated $\mathrm{Ca}_{\mathrm{V}} \alpha 1$ domains involve activation of a component of the UPR?}

We showed in our previous report (Raghib et al., 2001) that $\mathrm{Ca}_{\mathrm{V}} 2.2$ protein levels were reduced when the channel was coexpressed with $\mathrm{Ca}_{\mathrm{V}}$ 2.2-Dom I-II. One process that might mediate this reduction is the UPR. This response is initiated when the ER lumen is unable to cope with the load of newly synthesized proteins requiring folding (Harding et al., 2002). An early consequence is translation inhibition mediated by the ER-resident PERK (Harding et al., 2000). To examine whether this pathway is involved in the suppression of expression of $\mathrm{Ca}_{\mathrm{V}} 2$ channels by truncated constructs, we determined the effect of two dominantnegative PERK constructs on $\mathrm{Ca}_{\mathrm{V}} 2.2$ expression and its suppression by $\mathrm{Ca}_{\mathrm{V}} 2$ 2-2-Dom I. These were PERK K618A with a point mutation in its catalytic site and PERK $\Delta$ C lacking the C-terminal kinase domain, both of which prevent activation of endogenous PERK (Harding et al., 1999).

When $\mathrm{Ca}_{\mathrm{V}}$ 2.2-Dom I was coexpressed with $\mathrm{Ca}_{\mathrm{V}} 2.2$, together with the dominant-negative PERKs, a significant reversal of suppression was observed. With PERK K618A, there was only a $55.2 \%$ suppression of $\mathrm{Ca}_{\mathrm{V}} 2.2$ currents (Fig. $1 A, C$ ). PERK $\Delta \mathrm{C}$ also significantly reduced the suppressive effect of $\mathrm{Ca}_{\mathrm{V}} 2.2$-Dom I (Fig. $1 A)$. It has previously been shown that overexpression of wildtype PERK is able to produce some inhibition of translation, presumably by overwhelming the mechanisms that suppress dimerization and activation of endogenous PERK (Harding et al., 1999). In agreement with this, when wild-type PERK was coexpressed with $\mathrm{Ca}_{\mathrm{V}} 2.2$ in the absence of any truncated constructs, it reduced $\mathrm{Ca}_{\mathrm{V}} 2.2 \mathrm{I}_{\mathrm{Ba}}$ by $71.1 \%$ (Fig. $1 B, C$ ), indicating that overexpression of PERK itself is able to suppress translation of calcium channels. The PERK K618A mutant, which is unable to suppress translation (Harding et al., 1999), was ineffective in this regard (Fig. $1 B, C$ ). These results indicate that activation of PERK plays a role in the suppression of $\mathrm{Ca}_{\mathrm{V}} 2.2$ currents by truncated domains. In agreement with this finding, thapsigargin, which is a global initiator of UPR and an activator of PERK (Harding et al., 1999), had a similar effect. Continuous incubation of Xenopus oocytes with thapsigargin $(1 \mu \mathrm{M})$ from $12 \mathrm{hr}$ after cDNA injection inhibited $\mathrm{Ca}_{\mathrm{V}} 2.2$ current expression by $\sim 90 \%$ (Fig. $1 C$ ). These oocytes were visually healthy and had normal holding currents at $-100 \mathrm{mV}$.

\section{Does activation of PERK play a role in dominant-negative suppression of $\mathrm{Ca}_{\mathrm{v}} 2.1$ by the truncated protein predicted by an EA2 mutation?}

Truncated $\mathrm{Ca}_{\mathrm{V}} 2.1$ channels are potentially expressed as a result of a number of EA2 mutations. We examined the effect of an EA2 mutation at the beginning of domain III, caused by a single base pair deletion at $\mathrm{C}_{4073}$ (Ophoff et al., 1996) that predicts expression of a two-domain isoform. We first determined whether it would produce a dominant-negative effect in the same way as truncated $\mathrm{Ca}_{\mathrm{V}} 2.2$ constructs. When the EA2 mutant construct $\left(\mathrm{Ca}_{\mathrm{V}} 2.1-\mathrm{P} 1217 \mathrm{fs}\right)$ was expressed from cDNA in Xenopus oocytes, together with $\alpha 2 \delta$ - 2 and $\beta 4$ to mimic Purkinje cell calcium channels (Barclay et al., 2001), it inhibited $\mathrm{Ca}_{\mathrm{V}} 2.1$ currents by $93 \%$ (Fig. 2A; Table 1). These data were confirmed using COS-7 cells, in which the reduction was $94 \%$ (Table 1).

We next examined the effect of coexpression of both dominant-negative PERK constructs on $\mathrm{Ca}_{\mathrm{V}} 2.1$ expression and 
Table 1. Effects of truncated calcium channel constructs on the expression of voltage-gated calcium channel currents

\begin{tabular}{|c|c|c|c|c|c|}
\hline Full-length channel & Truncated domain or construct & Cell type (units) & Control peak current $(n)$ & $\begin{array}{l}\text { Current plus truncated } \\
\text { domain }(n)\end{array}$ & $\begin{array}{l}\text { Percentage of reduction } \\
\text { in current }\end{array}$ \\
\hline $\mathrm{Ca}_{\mathrm{v}} 2.2 / \alpha 2 \delta-2 / \beta 1 \mathrm{~b}$ & $C a_{\mathrm{v}} 2.2-\mathrm{Dom} \mathrm{I}$ & 0ocytes $(\mu \mathrm{A})$ & $-1.64 \pm 0.11(62)$ & $-0.21 \pm 0.04(46)$ & $87.0 \pm 2.2^{* *}$ \\
\hline $\mathrm{Ca}_{\mathrm{v}} 2.2 / \alpha 2 \delta-2 / \beta 1 \mathrm{~b}$ & Kir2.1-AAA & 0ocytes $(\mu \mathrm{A})$ & $-0.81 \pm 0.14(30)$ & $-0.87 \pm 0.10(35)$ & $-2.4 \pm 10.7$ \\
\hline $\mathrm{Ca}_{\mathrm{v}} 2.1 / \alpha 2 \delta-2 / \beta 4$ & $\mathrm{Ca}_{\mathrm{v}} 2.1-\mathrm{P} 1217 \mathrm{fs}$ & Oocytes $(\mu \mathrm{A})$ & $-0.68 \pm 0.14(22)$ & $-0.05 \pm 0.01(20)$ & $92.5 \pm 1.8^{* *}$ \\
\hline$C a_{v} 2.1 / \alpha 2 \delta-2 / \beta 4$ & $\mathrm{Ca}_{\mathrm{v}} 2.1-\mathrm{P} 1217 \mathrm{fs}$ & $\cos -7$ (pA/pF) & $-46.4 \pm 11.7(9)$ & $-2.9 \pm 1.7(3)$ & $93.8 \pm 3.7^{* *}$ \\
\hline$C a_{v} 2.1 / \alpha 2 \delta-2 / \beta 4$ & $\mathrm{Ca}_{\mathrm{v}} 2.2-\mathrm{Dom} \mathrm{I}-\mathrm{II}$ & tsA201 (pA/pF) & $-150.4 \pm 47.0(12)$ & $-90.2 \pm 24.9(12)$ & $40.1 \pm 16.6^{*}$ \\
\hline $\mathrm{Ca}_{\mathrm{v}} 2.3 / \alpha 2 \delta-1 / \beta 1 \mathrm{~b}$ & $\mathrm{Ca}_{\mathrm{v}} 2.2-\mathrm{Dom} \mathrm{I}-\mathrm{II}$ & $\cos -7(p A / p F)$ & $-69.0 \pm 17.7(8)$ & $-35.7 \pm 14.1(9)$ & $48.2 \pm 20.5^{*}$ \\
\hline $\mathrm{Ca}_{\mathrm{v}} 2.2 / \alpha 2 \delta-2 / \beta 1 \mathrm{~b}$ & $C a_{v} 2.1-P 1217 f s$ & tSA201 (pA/pF) & $-195.1 \pm 42.0(11)$ & $-97.1 \pm 25.9(17)$ & $50.2 \pm 13.2^{*}$ \\
\hline $\mathrm{Ca}_{\mathrm{v}} 3.1$ & Ca $a_{v}$ 3.1-Dom I & tsA-201 (pA/pF) & $-59.4 \pm 10.3(27)$ & $-21.9 \pm 3.9(24)$ & $63.0 \pm 6.6^{* *}$ \\
\hline $\mathrm{Ca}_{\mathrm{v}} 3.1$ & $C a_{v}$ 3.1-Dom I-II & tsA-201 (pA/pF) & $-86.2 \pm 16.5(25)$ & $-43.3 \pm 9.8(25)$ & $49.9 \pm 11.4^{*}$ \\
\hline $\mathrm{Ca}_{\mathrm{v}} 3.2$ & $C a_{v} 3.2-D o m l$ & tsA-201 (pA/pF) & $-75.4 \pm 11.3(15)$ & $-8.0 \pm 0.98(9)$ & $89.4 \pm 1.3^{* *}$ \\
\hline $\mathrm{Ca}_{\mathrm{v}} 3.1$ & $C a_{v} 2.2-D o m l$ & tsA-201 (pA/pF) & $-63.1 \pm 21.8(14)$ & $-49.9 \pm 10.8(11)$ & $20.9 \pm 17.0$ \\
\hline$C a_{v} 3.1$ & $\mathrm{Ca}_{\mathrm{v}} 2.2-$-Dom I-II & $\operatorname{COS}-7$ (pA/pF) & $-39.5 \pm 10.0(11)$ & $-44.0 \pm 13.6(11)$ & $-11.5 \pm 34.5$ \\
\hline$C a_{v} 3.1$ & $\mathrm{Ca}_{\mathrm{v}} 2.1-\mathrm{P} 1217 \mathrm{fs}$ & $\cos -7(p A / p F)$ & $-41.3 \pm 9.8(10)$ & $-41.6 \pm 10.7(10)$ & $-0.66 \pm 26.0$ \\
\hline $\mathrm{Ca}_{\mathrm{v}} 2.2 / \alpha 2 \delta-2 / \beta 1 \mathrm{~b}$ & $C a_{v} 3.1-D o m I$ & tsA-201 (pA/pF) & $-84.5 \pm 23.7(10)$ & $-96.0 \pm 31.7(8)$ & $-13.5 \pm 37.5$ \\
\hline
\end{tabular}

All conditions in the same row were performed in parallel to circumvent variability between batches of cells or oocytes. Data were confirmed in at least two different experiments. The inhibition was determined for the mean peak $\mathrm{I}_{\mathrm{Ba}}$. For oocytes, this was $0 \mathrm{mV}$ for $\mathrm{Ca}_{\mathrm{y}} 2.2,-5 \mathrm{mV}$ for $\mathrm{Ca}_{\mathrm{v}} 2.1$ and $\mathrm{Ca}_{\mathrm{y}} 1.2$, and $+5 \mathrm{mV}$ for $\mathrm{Ca}_{\mathrm{y}} 1.2$, in $5 \mathrm{~mm} \mathrm{Ba}{ }^{2+}$. In mammalian cells, peak $\mathrm{I}_{\mathrm{Ba}}$ was $+10 \mathrm{mV}$ for $\mathrm{Ca}_{\mathrm{v}} 2.1,+20 \mathrm{mV}$ for $\mathrm{Ca}_{\mathrm{v}} 2.2$, and $-10 \mathrm{mV}$ for $\mathrm{Ca}_{\mathrm{v}} 3.1$ and $\mathrm{Ca}_{\mathrm{v}} 3.2$, all in $10 \mathrm{~mm} \mathrm{Ba}{ }^{2+}$. Statistical significance: ${ }^{* *} p<0.0001 ;{ }^{*} p<0.05$; Student's $t$ test.

its suppression by $\mathrm{Ca}_{\mathrm{V}} 2.1-\mathrm{P} 1217 \mathrm{fs}$. There was a significant reduction in the suppression of peak $\mathrm{I}_{\mathrm{Ba}}$, for both PERK K618A and PERK $\triangle C$, to 62.6 and $46.8 \%$ suppression, respectively (Fig. $2 B, C)$. These results indicate that PERK activation also plays a part in the suppression of $\mathrm{Ca}_{\mathrm{V}} 2.1$ currents by $\mathrm{Ca}_{\mathrm{V}} 2.1-\mathrm{P} 1217 \mathrm{fs}$.

Confirmation of the presence of endogenous PERK in oocytes For the kinase-dead PERK $\Delta \mathrm{C}$ and PERK-K618A constructs to behave in a dominant-negative manner, they must interact with native PERK to form nonfunctional dimers, and it was therefore imperative to demonstrate the expression of PERK in Xenopus oocytes. The PERK gene is highly conserved, and we identified, by RT-PCR, a transcript with strong sequence homology to murine PERK in Xenopus oocytes. A 425 aa fragment encompassing the ER lumenal domain and part of the TM domain showed $81 \%$ identity and $90 \%$ similarity with mouse PERK used in the present study. Published EST sequences BU912964 and CA791610 were also expressed in oocytes and showed a similar level of homology within the two lobes of the kinase domain (93\% identity, 98\% similarity with the first lobe and $83 \%$ identity, 91\% similarity with the second lobe of the kinase domain in mouse PERK). Endogenous PERK mRNA, measured by QPCR, was not altered by coexpression of $\mathrm{Ca}_{\mathrm{V}} 2.2$ and $\mathrm{Ca}_{\mathrm{V}} 2.2$-Dom I (data not shown), in agreement with previous evidence that its activity is upregulated by phosphorylation (Harding et al., 1999) rather than increased expression.

\section{Does the suppression of $\mathrm{Ca}_{\mathrm{V}}$ expression by truncated constructs involve interaction between full-length and truncated channels?}

The activation of PERK might be triggered either by the truncated domain alone or by its interaction with the full-length $\mathrm{Ca}_{\mathrm{V}} 2$ channel. To examine this issue, we studied the specificity of inhibition between different calcium channel family members. Because the TM segments, as well as the $\mathrm{N}$ termini and proximal $\mathrm{C}$ termini of all the $\mathrm{Ca}_{\mathrm{V}} 2$ channels, are very similar, we examined first whether there would be cross-suppression between different pairs of full-length and truncated channels within the $\mathrm{Ca}_{\mathrm{V}} 2 \mathrm{cal}-$ cium channel family. We found that $\mathrm{Ca}_{\mathrm{V}} 2.2-\mathrm{Dom}$ I-II markedly inhibited both $\mathrm{Ca}_{\mathrm{V}} 2.1$ and $\mathrm{Ca}_{\mathrm{V}} 2.3$ currents by 40 and $48 \%$, respectively (Table 1), and reciprocally $\mathrm{Ca}_{\mathrm{V}} 2.1-\mathrm{P} 1217 \mathrm{fs}$ inhibited $\mathrm{Ca}_{\mathrm{V}} 2.2$ currents by $50 \%$ (Table 1 ). From these results, although we have not examined every combination, it appears that there is a generalized cross-suppression by truncated domains within the $\mathrm{Ca}_{\mathrm{V}} 2$ family.

\section{Cross-suppression does not occur between the $\mathrm{Ca}_{\mathrm{v}} 2$ and $\mathrm{Ca}_{\mathrm{v}} 3$ families}

We extended our investigation of cross-suppression to the more distantly related $\mathrm{Ca}_{\mathrm{V}} 3$ calcium channels. There is currently no evidence that truncated $\mathrm{Ca}_{\mathrm{V}} 3$ channels are expressed physiologically or pathologically, but this remains a possibility. First, we examined whether truncated constructs of the $\mathrm{Ca}_{\mathrm{V}} 3$ family could inhibit the expression of the cognate full-length $\mathrm{Ca}_{\mathrm{V}} 3$ channels. Both $\mathrm{Ca}_{\mathrm{V}}$ 3.1-Dom I and $\mathrm{Ca}_{\mathrm{V}}$ 3.1-Dom I-II markedly inhibited $\mathrm{Ca}_{\mathrm{V}} 3.1$ currents by 63 and $50 \%$, respectively (Fig. $3 A, B$; Table 1). Furthermore, $\mathrm{Ca}_{\mathrm{V}} 3.2$-Dom I inhibited $\mathrm{Ca}_{\mathrm{V}} 3.2$ currents by $89 \%$ (Table 1 ). The inhibition of $\mathrm{Ca}_{\mathrm{V}} 3.1$ by $\mathrm{Ca}_{\mathrm{V}} 3.1-$ Dom I was also associated with a suppression of protein expression by $86 \%$ (Fig. $3 C$ ).

To study whether the cross-suppression extended between the $\mathrm{Ca}_{\mathrm{V}} 2$ and $\mathrm{Ca}_{\mathrm{V}} 3$ subfamilies, we examined whether any truncated domains of $\mathrm{Ca}_{\mathrm{V}} 2.1$ or $\mathrm{Ca}_{\mathrm{V}} 2.2$ would inhibit $\mathrm{Ca}_{\mathrm{V}} 3.1$ currents. No significant inhibition was observed by $\mathrm{Ca}_{\mathrm{V}} 2.2-\mathrm{Dom} \mathrm{I}, \mathrm{Ca}_{\mathrm{V}} 2.2$ Dom I-II, or $\mathrm{Ca}_{\mathrm{V}}$ 2.1-P1217fs (Fig. 4A; Table 1), indicating that there is a specificity in the process of suppression. In agreement with this, there was little effect of $\mathrm{Ca}_{\mathrm{V}} 2.2$-Dom I-II on $\mathrm{Ca}_{\mathrm{V}} 3.1$ protein levels (Fig. $4 B$ ). The specificity of cross-suppression is further borne out by the lack of effect of $\mathrm{Ca}_{\mathrm{V}} 3.1-\mathrm{Dom} \mathrm{I}$ on $\mathrm{Ca}_{\mathrm{V}} 2.2$ currents (Fig. 4C; Table 1). These results strongly suggest that the suppression of $\mathrm{Ca}_{\mathrm{V}}$ currents by truncated constructs is triggered primarily by an interaction of the truncated channel in the ER with a related channel.

\section{What is effect of coexpression of a truncated domain on $\mathrm{Ca}_{\mathrm{v}}$ 2.2 protein and $\mathrm{mRNA}$ levels?}

Our working hypothesis for the sequence of events leading to suppression of $\mathrm{Ca}_{\mathrm{V}}$ channel expression is that the truncated domains, being much smaller than the full-length $\mathrm{Ca}_{\mathrm{V}}$, would be synthesized in the ER more rapidly than the full-length channels. Both $\mathrm{Ca}_{\mathrm{V}}$ 2.2-Dom I and $\mathrm{Ca}_{\mathrm{V}}$ 2.2-Dom I-II are detectable by Western blotting $8 \mathrm{hr}$ after transfection of COS-7 cells, whereas fulllength $\mathrm{Ca}_{\mathrm{V}} 2.2$ only begins to be expressed between 20 and $32 \mathrm{hr}$ after transfection (data not shown). The truncated channels would then be able to interact with the nascent full-length channels, possibly during the process of their synthesis, forming an aggregate that could not be trafficked out of the ER. We hypoth- 


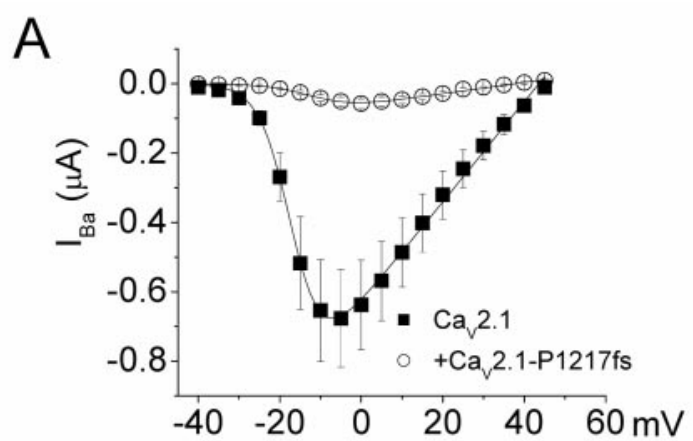

B

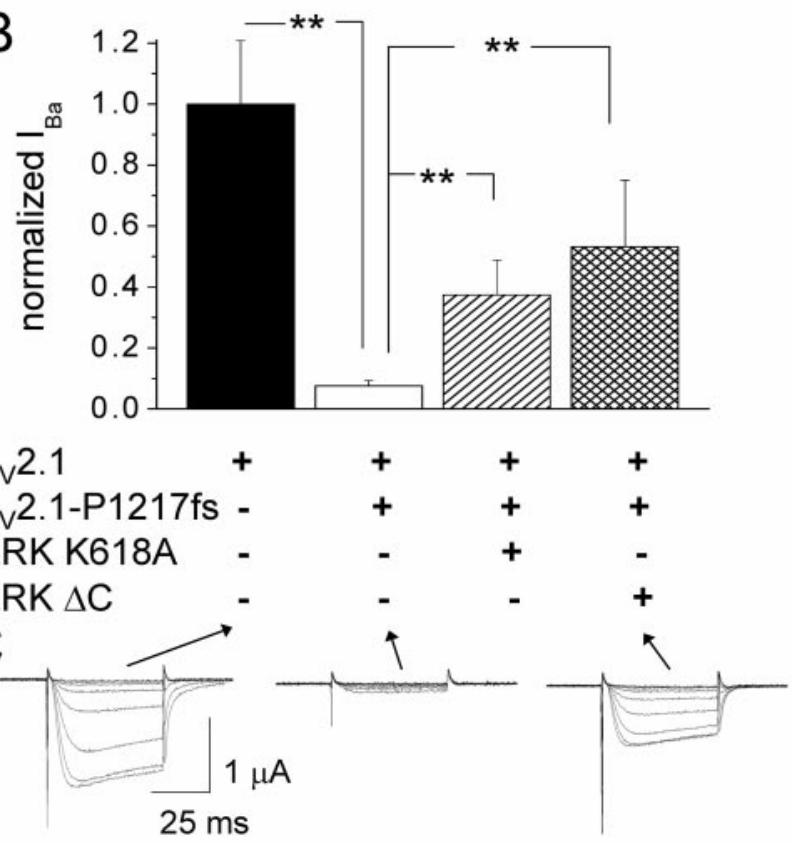

Figure 2. The effect of dominant-negative PERK constructs on suppression of $\mathrm{Ca}_{\mathrm{V}} 2.1 \mathrm{I}_{\mathrm{Ba}}$ by $C_{a} 2.1-P 1217 f s . A$, Mean $/-V$ plot for $\mathrm{Ca}_{\mathrm{v}} 2.1 / \alpha 2 \delta-2 / \beta 4$ expressed in Xenopus 0ocytes without $(\square ; n=22)$ or with $(O ; n=20) \mathrm{Ca}_{\mathrm{v}} 2.1-\mathrm{P} 1217 \mathrm{fs} \mathrm{I}_{\mathrm{Ba}}$. The $I-V$ plots gave maximum conductance $\left(G_{\text {max }}\right)$ values of 14.4 and $1.65 \mu$, respectively. $B$, Histogram of mean peak $I_{B a}$ for control $(\square ; n=22)$ in the presence of $\mathrm{Ca}_{\mathrm{v}} 2.1$-P1217fs $(\square ; n=20), \mathrm{Ca}_{\mathrm{v}} 2.1$-P1217fs plus PERK K618A (四; $n=9)$, or Ca 2.1-P1217fs plus PERK $\Delta C$ (爽; $n=6)$. The mean peak $\mathrm{I}_{\mathrm{Ba}}$ is expressed relative to control. Statistical significance as indicated: ${ }^{* *} p<0.001$. C, Representative $I_{B a}$ under three conditions: left, $\mathrm{Ca}_{\mathrm{v}} 2.1 / \beta 4 / \alpha 2 \delta$-2; center, plus $\mathrm{Ca}_{\mathrm{v}} 2.1-\mathrm{P} 1217 \mathrm{fs}$; right, plus $\mathrm{Ca}_{\mathrm{v}} 2.1$ $\mathrm{P} 1217 \mathrm{fs}$ and PERK $\Delta C$. The calibration bar refers to all panels. Traces are shown in $5 \mathrm{mV}$ steps between -40 and $-5 \mathrm{mV}$.

esize that this would then activate PERK and prevent additional translation. We therefore examined the effect of the $\mathrm{Ca}_{\mathrm{V}} 2.2$-Dom I on the level of full-length $\mathrm{Ca}_{\mathrm{V}} 2.2$ protein under the different conditions. In parallel with the suppressive effect of $\mathrm{Ca}_{\mathrm{V}} 2.2$-Dom I observed electrophysiologically, $\mathrm{Ca}_{\mathrm{V}} 2.2$ protein was reduced by $\sim 80 \%$, both in COS-7 cells (Fig. $5 A$ ) and in Xenopus oocytes (Fig. $5 B)$. This is in agreement with the main effect of the activation of PERK being inhibition of translation (Harding et al., 1999). In oocytes showing elevated currents on coexpression of PERKK618A, from which recordings were made for Figure $1 C$, there was a smaller reduction in $\mathrm{Ca}_{\mathrm{V}} 2.2$ protein (Fig. $5 B$ ). Expression of the $\alpha 2 \delta$-2 subunit protein, which is also synthesized on the ER and is highly glycosylated, was also markedly suppressed by $73 \%$ when coexpressed with $\mathrm{Ca}_{\mathrm{V}} 2.2 / \beta 1 \mathrm{~b}$ and $\mathrm{Ca}_{\mathrm{V}} 2.2$-Dom $\mathrm{I}(n=10)$ (Fig. $5 C$ ), whereas there was little suppression of expression of the cytoplasmic $\beta 1$ b subunit $(n=10)$ (Fig. $5 C$ ).
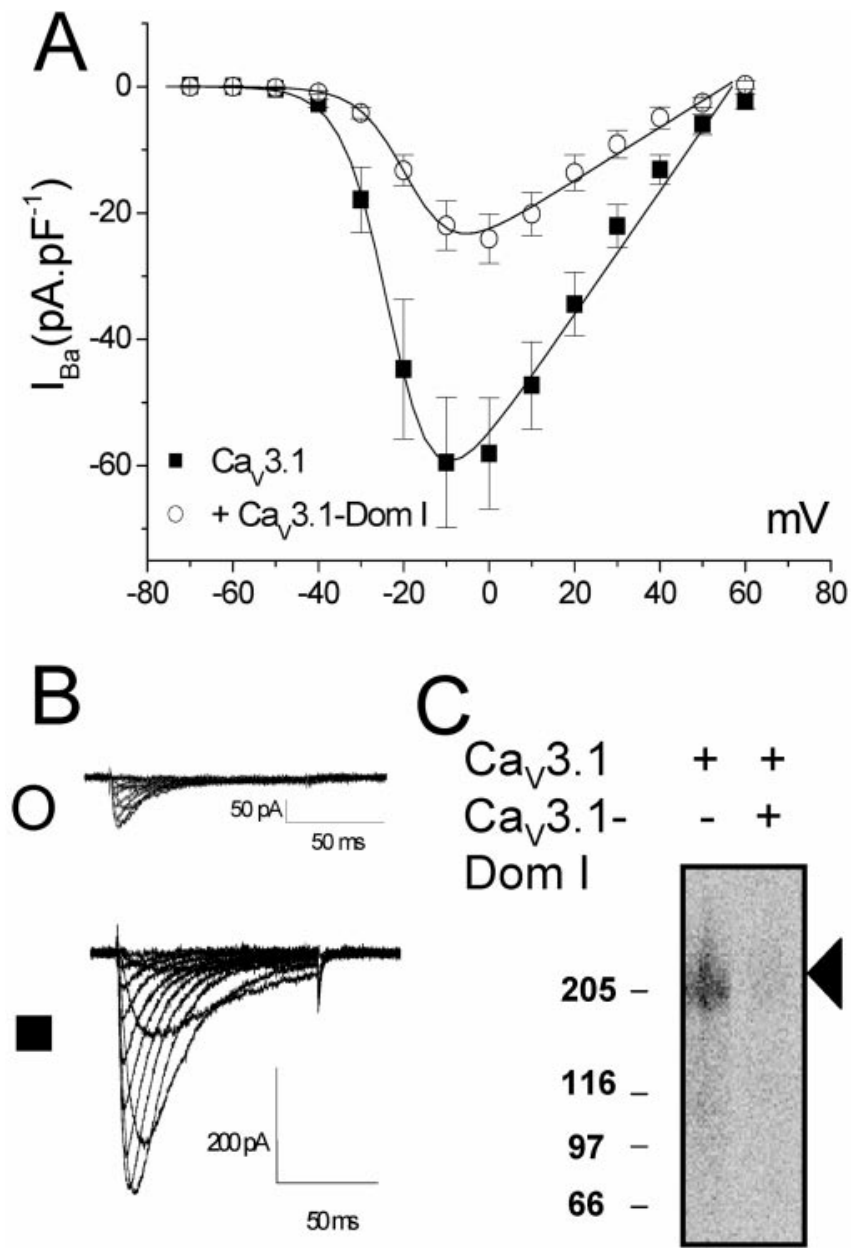

Figure 3. Suppression of $\mathrm{Ca}_{V} 3.1$ by Ca $3.1-D o m$ I. $A$, Suppression of $\mathrm{Ca}_{V} 3.1 \mathrm{I}_{\mathrm{Ba}}$ by $\mathrm{Ca}_{V} 3.1$ Dom I in tsA-201 cells $\left(10 \mathrm{~mm} \mathrm{Ba}^{2+}\right)$. I-V plots for $\mathrm{Ca}_{\mathrm{V}} 3.1$ expressed without $(\mathbf{\square} ; n=27)$ or with $(\bigcirc ; n=24) \mathrm{Ca}_{\mathrm{v}} 3.1-\mathrm{Dom} \mathrm{I}$. The mean $I-V$ plots gave maximum conductance $\left(G_{\max }\right)$ values of 0.98 and $0.55 \mathrm{nS} \cdot \mathrm{pF}^{-1}$, respectively. $B$, Representative family of traces from -70 to +60 $\mathrm{mV}$ for Ca 3.1 expressed with (top) or without (bottom) Ca 3 3.1-Dom I. C, Representative immunoblot showing the effect of $\mathrm{Ca}_{\mathrm{v}} 3.1$-Dom I on Ca 3.1 protein in COS-7 cells. Left lane, Ca 3.1 alone (indicated by arrowhead); right lane, $\mathrm{Ca}_{\mathrm{v}} 3.1$ plus $\mathrm{Ca}_{\mathrm{v}} 3.1-\mathrm{Dom}$ I. The reduction was $85.7 \pm 1.7 \%(n=4)$.

In agreement with the marked effect of thapsigargin $(1 \mu \mathrm{M})$ on the level of $\mathrm{Ca}_{\mathrm{V}} 2.2$ currents expressed in Xenopus oocytes, it also produced a striking reduction in $\mathrm{Ca}_{\mathrm{V}} 2.2, \alpha 2 \delta$ - 2 and $\beta 1 \mathrm{~b}$ protein levels by 93,67 , and $90 \%$, respectively $(n=3)$ (Fig. $5 D)$. Overexpression of PERK itself, together with $\mathrm{Ca}_{\mathrm{V}} 2.2 / \beta 1 \mathrm{~b} / \alpha 2 \delta$-2, also reduced calcium channel subunit levels in Xenopus oocytes, in agreement with its effect on $\mathrm{Ca}_{\mathrm{v}} 2.2$ currents. The $\alpha 2 \delta-2$ and $\beta 1 \mathrm{~b}$ protein levels were $70.5 \pm 5.8 \%$ and $65.6 \pm 6.7 \%$ of control $(n=7)$.

We also examined whether the proteasomal pathway was involved in the loss of $\mathrm{Ca}_{\mathrm{V}} 2.2$ protein induced by coexpression with $\mathrm{Ca}_{\mathrm{V}}$ 2.2-Dom I. However, we observed no effect of incubation of COS-7 cells with lactacystin ( $30 \mu \mathrm{M}$; replaced twice during the 48 hr period between transfection and harvesting) on $\mathrm{Ca}_{\mathrm{V}} 2.2$ protein levels or on the appearance of high molecular weight $\mathrm{Ca}_{\mathrm{V}} 2.2$ immunoreactive species that might represent poly-ubiquitinated $\mathrm{Ca}_{\mathrm{V}} 2.2$ in the presence of $\mathrm{Ca}_{\mathrm{V}} 2.2$-Dom I (data not shown).

If PERK is activated, resulting in phosphorylation of its substrate eIF2 $\alpha$, translation initiation will be prevented and there will be ribosome disassembly. The binding of nonphosphorylated eIF $2 \alpha$ is involved in the process of association of the two ribosomal subunits (Pestova et al., 2001). In general, mRNA is 
A
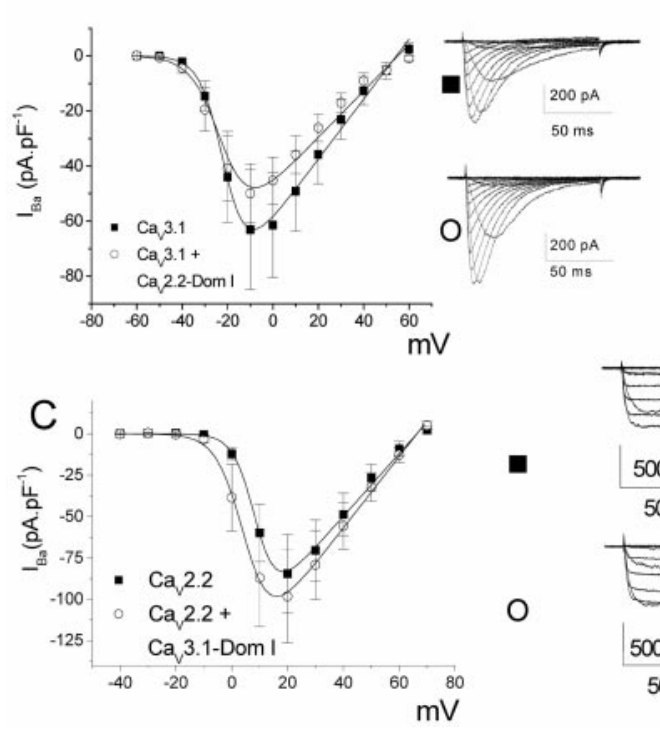

Figure 4. Lack of cross-suppression between $\mathrm{Ca}_{\mathrm{v}} 2.2$ and $\mathrm{Ca}_{\mathrm{v}} 3.1$ channels. $A$, Left, Lack of cross-suppression of $\mathrm{Ca}_{\mathrm{v}} 3.1 \mathrm{I}_{\mathrm{Ba}}$ by $\mathrm{Ca}_{\mathrm{v}} 2.2$-Dom I in tsA-201 cells recorded in $10 \mathrm{~mm} \mathrm{Ba}^{2+}$. I-V relationship for $\mathrm{Ca}_{\mathrm{V}} 3.1 \mathrm{I}_{\mathrm{Ba}}$ expressed without $(\mathbf{\square}, n=14)$ or with $(O ; n=11) \mathrm{Ca}_{\mathrm{V}} 2.2$-Dom I. The mean $I-V$ plots gave maximum conductance $\left(G_{\max }\right)$ values of 1.09 and 0.86 $n S \cdot \mathrm{pF}^{-1}$, respectively. Right, Representative family of traces from -60 to $+60 \mathrm{mV}$ for $\mathrm{Ca}_{\mathrm{v}} 3.1$ expressed without (top) or with (bottom) Ca 2 2.2-Dom I. B, Representative immunoblot showing the effect of $\mathrm{Ca}_{\mathrm{v}} 2.2-\mathrm{Dom} \mathrm{I}-\mathrm{Il}$ on $\mathrm{Ca}_{\mathrm{v}}$ 3.1-myc His(10) protein. Left lane, Ca 3.1-myc His(10) alone (indicated by arrowhead; detected with anti-myc $\mathrm{Ab}$ ); right lane, $\mathrm{Ca}_{\mathrm{v}} 3.1$-myc $\mathrm{His}$ (10) plus

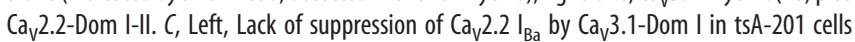
recorded in $10 \mathrm{~mm} \mathrm{Ba}^{2+}$. The $I-V$ relationship for $\mathrm{Ca}_{\mathrm{v}} 2.2 \mathrm{I}_{\mathrm{Ba}}$ expressed without $(\boldsymbol{\square}, n=10)$ or with $(O ; n=9) \mathrm{Ca}_{\mathrm{v}} 3.1$-Dom $\mathrm{I}$ is shown. The mean $I-V$ plots gave $G_{\max }$ values of 1.89 and 2.16 $n S \cdot \mathrm{pF}^{-1}$, respectively. Right, Representative family of traces from -40 to $+70 \mathrm{mV}$ for Ca 2.2 expressed without (top) or with (bottom) Cav3.1-Dom I.

stabilized by association with intact ribosomes (Mazumder et al., 2003). To examine whether there might therefore be a secondary effect on $\mathrm{Ca}_{\mathrm{V}} 2.2$ mRNA levels of interaction between the fulllength and the truncated $\mathrm{Ca}_{\mathrm{V}} 2.2$ proteins, we coexpressed $\mathrm{Ca}_{\mathrm{V}}$ 2.2-Dom I with full-length $\mathrm{Ca}_{\mathrm{V}} 2.2$ and accessory subunits and examined mRNA levels in individual Xenopus oocytes injected with cDNA. Because the stability of $\mathrm{Ca}_{\mathrm{V}} 2.2 \mathrm{mRNA}$ has also been shown to be governed by sequences in the $3^{\prime}$ UTR (Schorge et al., 1999), in the present study the 3' UTR was removed from the $\mathrm{Ca}_{\mathrm{V}} 2.2$ construct used for the oocyte expression experiments. In all these oocytes, $\mathrm{I}_{\mathrm{Ba}}$ was measured to ensure expression. From QPCR measurements, $\mathrm{Ca}_{\mathrm{V}}$ 2.2-Dom I reduced full-length $\mathrm{Ca}_{\mathrm{V}} 2.2$ mRNA by $63.4 \%$ (Fig. $6 A$ ). This suppression is not a nonspecific effect of the inclusion of additional cDNA for a TM protein because inclusion of Kir2.1-AAA, in place of $\mathrm{Ca}_{\mathrm{V}} 2.2$-Dom I cDNA, did not reduce the $\mathrm{Ca}_{\mathrm{V}} 2.2$ mRNA level (Fig. 6B). However, when Kir2.1-AAA cDNA was included together with $\mathrm{Ca}_{\mathrm{V}} 2.2$-Dom I and $\mathrm{Ca}_{\mathrm{V}}$ 2.2, the Kir2.1-AAA mRNA was also reduced by $63.7 \%$ (Fig. 6C). This reduction requires the presence of both the full-length and the truncated calcium channel because Kir2.1-AAA mRNA was not reduced by $\mathrm{Ca}_{\mathrm{V}} 2.2$-Dom I when $\mathrm{K}_{\mathrm{V}} 3.1 \mathrm{cDNA}$ was included in place of $\mathrm{Ca}_{\mathrm{V}} 2.2$ (Fig. 6D), in agreement with the lack of effect of $\mathrm{Ca}_{\mathrm{V}} 2.2-$ Dom I on $K_{V} 3.1$ currents. The reduction of Kir2.1-AAA mRNA, when it is coexpressed with $\mathrm{Ca}_{\mathrm{V}} 2.2$ and $\mathrm{Ca}_{\mathrm{V}} 2.2$-Dom I, indicates that there is a global effect at least on mRNAs translated on ER-associated ribosomes. In general, this result indicates that a component of the suppression of $\mathrm{Ca}_{\mathrm{V}} 2.2$ currents by $\mathrm{Ca}_{\mathrm{V}} 2.2$-Dom I is also likely to involve degradation of mRNA.
In agreement with these results, $\mathrm{Ca}_{\mathrm{V}} 2.2$-Dom I was less effective in suppressing $\mathrm{Ca}_{\mathrm{V}} 2.2$ currents when all constructs were expressed from synthetically capped mRNA injection into Xenopus oocytes. Coexpression of $\mathrm{Ca}_{\mathrm{V}} 2.2$-Dom I mRNA with $\mathrm{Ca}_{\mathrm{V}} 2.2$ produced a $48.6 \pm 5.4 \%$ inhibition $(n=20 ; p<0.01$ compared with $\mathrm{Ca}_{\mathrm{V}} 2.2$ alone) of the maximum $\mathrm{I}_{\mathrm{Ba}}$. Injection of twice the amount of $\mathrm{Ca}_{\mathrm{V}}$ 2.2-Dom I mRNA only produced a small additional suppression of $\mathrm{Ca}_{\mathrm{V}} 2.2$ currents, to $58.4 \%$ inhibition $(n=22$; $p<$ 0.01 compared with $\mathrm{Ca}_{\mathrm{V}} 2.2$ ).

\section{Do truncated $\mathrm{Ca}_{\mathrm{V}} \alpha 1$ constructs inhibit endogenous calcium channels?}

For the mechanism described here to be relevant to developmental or disease states and also to have potential as a tool to knock down calcium channel function, it is necessary to show that the truncated channel constructs can inhibit native calcium currents. For this, we used two cell lines with neuronal phenotypes, PC12 and NG108-15. The PC12 cell line used in this study had a very low density of calcium channels when undifferentiated (Fig. 7A) but expressed high voltage activated (HVA) currents when differentiated with NGF. After $5 \mathrm{~d}$ of differentiation, peak $\mathrm{I}_{\mathrm{Ba}}$ was increased from -5.4 to $-19.9 \mathrm{pA} / \mathrm{pF}$ (Fig. $7 A$ ), and this was reduced by $61.4 \%$ by $1 \mu \mathrm{M} \omega$-conotoxin GVIA. When cells were transfected with GFP-Ca $a_{\mathrm{V}}$ 2.2-Dom I-II and then differentiated, the peak HVA current amplitude was reduced by $84.9 \pm 8.2 \%$ compared with differentiated controls transfected with GFP and was no greater than that in undifferentiated cells (Fig. 7A). When PC12 cells were transfected with PERK, together with GFP and then differentiated, the peak currents were also reduced by $39.9 \%$ $(n=11)$ compared with cells transfected with cDNA for a control protein, Kir1.2-AAA, together with GFP.

NG108-15 cells contain endogenous T-type channels when undifferentiated and have been shown to express $\mathrm{Ca}_{\mathrm{V}} 3.2$ mRNA (Chemin et al., 2002). These cells were therefore transfected with $\mathrm{Ca}_{\mathrm{V}}$ 3.2-Dom I or Kir1.2-AAA as a control, together with GFP. Three days after transfection, the peak native T-type currents were reduced in the $\mathrm{Ca}_{\mathrm{V}} 3.2$-Dom I-transfected cells by $49.2 \pm$ $10.6 \%$ compared with control (Fig. $7 B$ ). There was no difference in any of the biophysical properties examined (voltage dependence of activation, time constant of inactivation) (Fig. $7 B$, traces) apart from current density.

\section{Discussion}

\section{Translational suppression of $\mathrm{Ca}_{\mathrm{v}} 2$ channel expression by} truncated domains involves the UPR

Accumulation of misfolded proteins within the ER triggers the UPR pathway (Mori, 2000; Liu and Kaufman, 2003). This pathway has been elucidated previously with global initiators of UPR, including thapsigargin, rather than by using specific unfolded proteins. In our study, thapsigargin suppressed $\mathrm{Ca}_{\mathrm{V}} 2.2$ currents and $\mathrm{Ca}_{\mathrm{V}} 2.2$ protein expression by a similar extent to $\mathrm{Ca}_{\mathrm{V}} 2.2-\mathrm{Dom}$ I. One of the important initiators of the UPR is the ER membrane-resident kinase PERK (Harding et al., 1999).

We used two mutant PERK constructs, PERK K618A and PERK $\Delta C$ (Harding et al., 1999), both of which lack kinase activity. Their dominant-negative behavior stems from the fact that they form nonfunctional dimers with endogenous PERK. The mutant PERKs markedly reduced the inhibition of $\mathrm{Ca}_{\mathrm{V}} 2.1$ expression by the EA2 mutant construct $\mathrm{Ca}_{\mathrm{V}} 2.1-\mathrm{P} 1217 \mathrm{fs}$ and the inhibition of $\mathrm{Ca}_{\mathrm{V}} 2.2$ expression by $\mathrm{Ca}_{\mathrm{V}} 2.2$-Dom I, while having no effect in the absence of the truncated channel. This implicates endogenous PERK in the process of suppression. The reversal of 
this suppression by the dominant-negative PERKs was rarely complete. One obvious reason is that, although the dominantnegative PERKs reduced the translational suppression, counter-productive interaction between full-length and truncated channels would still occur in the ER.

Although global initiators of ER stress such as thapsigargin cause a widespread inhibition of protein synthesis, it has been suggested that more localized activation of PERK, which is itself tethered in the ER, may restrict inhibition of translation to particular ER-bound ribosomes (Ron, 2002). In agreement with this hypothesis, we found that the level of $\mathrm{Ca}_{\mathrm{V}} \beta$ protein was not significantly affected by the coexpression of $\mathrm{Ca}_{\mathrm{V}} 2.2$ and $\mathrm{Ca}_{\mathrm{V}} 2.2$-Dom $\mathrm{I}$, whereas there was a consistent reduction in $\alpha 2 \delta$ - 2 expression. Being a highly glycosylated type I membrane protein, $\alpha 2 \delta$ - 2 is profoundly dependent on the ER for synthesis and maturation.

\section{The ER membrane-resident kinase PERK acts at the level of translation}

The primary effect of activation of PERK is suppression of capdependent translation initiation by phosphorylation of eIF $2 \alpha$ (Harding et al., 1999), which prevents the formation of the $80 \mathrm{~S}$ ribosome complex (Pestova et al., 2001), and our results indicate that this mechanism is involved in the suppression of $\mathrm{Ca}_{\mathrm{V}} 2.2$ expression by $\mathrm{Ca}_{\mathrm{V}} 2.2$-Dom I. However, in our study, there was also a consistent reduction in the $\mathrm{Ca}_{\mathrm{V}} 2.2 \mathrm{mRNA}$ level in the presence of $\mathrm{Ca}_{\mathrm{V}}$ 2.2-Dom I, which we hypothesized as being secondary to the activation of PERK for the following reasons. The effect of $\mathrm{Ca}_{\mathrm{V}} 2.2$-Dom I on $\mathrm{Ca}_{\mathrm{V}} 2.2$ currents and protein was much greater $\left(80-90 \%\right.$ decrease) than the effect on $\mathrm{Ca}_{\mathrm{V}} 2.2$ mRNA ( $\sim 60 \%$ decrease), suggesting that the reduction in mRNA is not the main cause of the loss of protein, although it would inevitably contribute to it. Phosphorylation of eIF $2 \alpha$ by PERK, which leads to ribosome disassembly and prevention of translation initiation, results directly in a reduction in translation, but secondarily it may cause an increased rate of mRNA degradation. It is known that when mRNA is associated with intact polysomes it is stabilized (e.g., by circularization with both the cap and the polyA tail being bound by the ribosome) (Sachs and Varani, 2000; Mazumder et al., 2003). However, it is also possible that other unknown parallel mechanisms are activated by the UPR to reduce transcription or mRNA stability.

\section{Interaction between truncated and full-length channel is required for suppression of calcium channel expression}

We observed cross-suppression between the different subclasses of $\mathrm{Ca}_{\mathrm{V}} 2$ channels $\left(\mathrm{Ca}_{\mathrm{V}} 2.1, \mathrm{Ca}_{\mathrm{V}} 2.2\right.$, and $\left.\mathrm{Ca}_{\mathrm{V}} 2.3\right)$, in which conservation within TM segments is very high. However, there was no significant cross-suppression between full-length $\mathrm{Ca}_{\mathrm{V}} 3.1$ and truncated constructs of $\mathrm{Ca}_{\mathrm{V}} 2.2$, and vice versa. This suggests that interaction occurs between the truncated domain and segments of a cognate full-length channel with which it shows an affinity.

Inappropriate intermolecular interactions, substituting for the appropriate intramolecular interactions that lead to the mature folded protein (so-called domain swapping) are generally the basis for pathological protein aggregation (for review, see Horwich, 2002). It is probable that truncated calcium channels interfere with one or more essential interactions between the domains within a single full-length channel required for it to fold into its mature form. We are currently investigating the specific domains involved in this interaction. The incorrectly assembled channels, aggregated with the truncated domain, are likely to remain in the ER and will then be in a position to trigger translational suppression by activation of PERK. This does not preclude the finding that some truncated channels may reach the plasma membrane, as was shown to occur previously (Ahern et al., 2001; Raghib et al., 2001).

Whereas we did not obtain evidence in the present study for the additional involvement of the proteasomal pathway, additional work is underway to examine ubiquitination of $\mathrm{Ca}_{\mathrm{V}} 2.2$.

\section{Lack of involvement of sequestration of the $\mathrm{Ca}_{\mathrm{v}} \boldsymbol{\beta}$ subunit}

Our evidence does not support the view that the major mechanism of suppression involves sequestration by truncated domains of $\mathrm{Ca}_{\mathrm{V}} \beta$ subunits. As described in our initial study, overexpression of the $\mathrm{Ca}_{\mathrm{V}} \alpha 1$ I-II linker to sequester $\beta$ subunits did not mimic suppression of $\mathrm{Ca}_{\mathrm{V}} 2.2$ currents or protein (Raghib et al., 2001 ), and $\mathrm{Ca}_{\mathrm{V}} 3.1$ current suppression occurred in the absence of $\mathrm{Ca}_{\mathrm{V}} \beta$ subunits. We also found that there was no depolarizing shift of steady-state inactivation associated with suppression, which would have been indicative of depletion of $\mathrm{Ca}_{\mathrm{V}} \beta$ subunits.

\section{Suppression of native calcium currents by truncated channel constructs}

We have shown that endogenous T-type and HVA calcium currents are substantially inhibited by relevant truncated constructs in neuronal cell lines. The complete suppression by $\mathrm{Ca}_{\mathrm{V}} 2.2-\mathrm{Dom}$ I-II of de novo synthesized HVA channels in PC12 cells is in accordance with the preferential enhancement of $\mathrm{N}$-type channel expression on differentiation with NGF (Usowicz et al., 1990). The smaller reduction of preexisting T-type currents in NG108-15 cells by $\mathrm{Ca}_{\mathrm{V}} 3.2$-Dom $\mathrm{I}$ is understandable because turnover of the existing T-type channels must also occur.

\section{Relationship to EA2 and other calcium channelopathies}

We have demonstrated the ability of a construct mimicking an EA2 mutation (Ophoff et al., 1996), which predicts the expression of the first two domains of $\mathrm{Ca}_{\mathrm{V}} 2.1$, to markedly suppress the expression of $\mathrm{Ca}_{\mathrm{V}} 2.1$ currents. This is in agreement with the work 


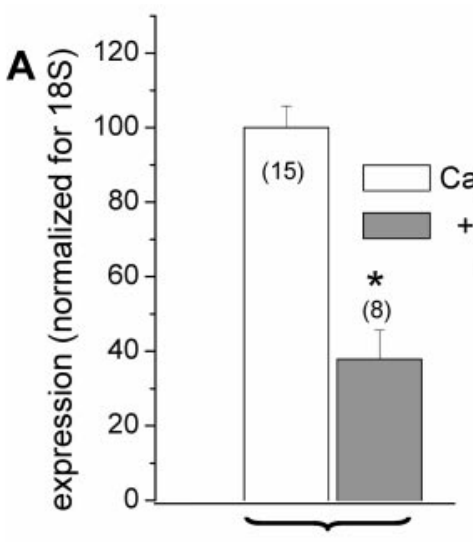

Primers: $\quad \mathrm{Ca}_{\mathrm{v}} 2.2$
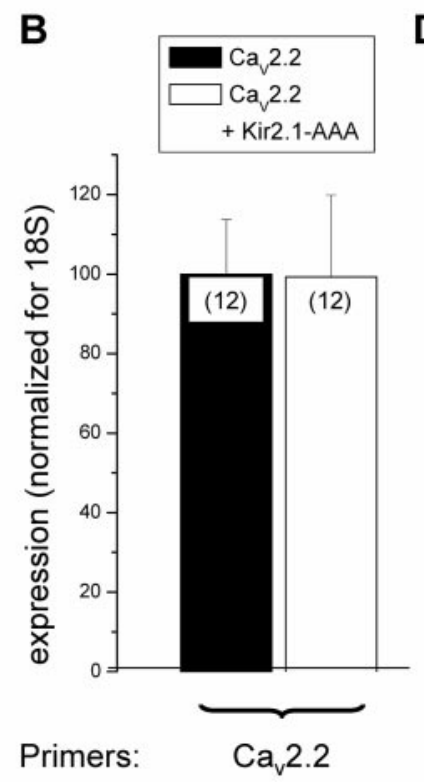

D
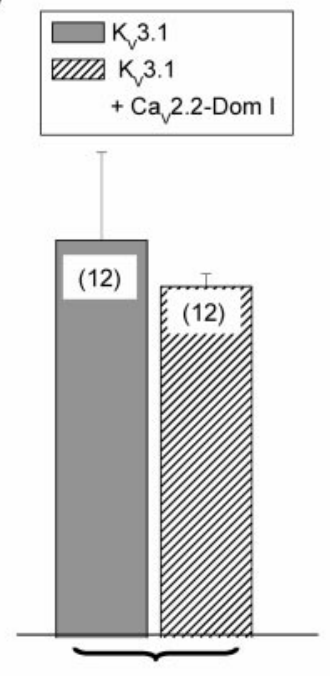

Kir2.1-AAA
Figure 6. The effect of $\mathrm{Ca}_{\mathrm{v}} 2.2-\mathrm{Dom}$ I on Ca 2.2 mRNA levels. $A, \mathrm{Ca}_{\mathrm{v}} 2.2, \beta 1 \mathrm{~b}, \alpha 2 \delta$-2, and Kir2.1-AAA were expressed in oocytes in the absence $(\square)$ or presence (罭) of $\mathrm{Ca}_{\mathrm{v}} 2.2-\mathrm{Dom} \mathrm{I}$. Real-time PCR was used to detect $\mathrm{Ca}_{\mathrm{v}} 2.2 \mathrm{mRNA}$ in individual oocytes. $B, \mathrm{Ca}_{\mathrm{v}} 2.2 \mathrm{mRNA}$ was measured in 0ocytes expressing $\mathrm{Ca}_{\mathrm{v}} 2.2, \beta 1 \mathrm{~b}$, and $\alpha 2 \delta$-2 in the absence $(\square)$ or presence $(\square)$ of Kir2.1-AAA. C, Kir2.1-AAA mRNA levels were measured in the same oocytes used in $A . D, K_{v} 3.1$ and Kir2.1-AAA were expressed in the absence (畻) or presence (跒) of Ca 2 2.1-Dom I. Kir2.1-AAA mRNA levels were measured. Data were normalized for the level of 185 ribosomal RNA, which was unaffected by expression of $\mathrm{Ca}_{\mathrm{v}} 2.2$-Dom I. Error bars are the percentage of coefficient of variation for the $n$ values shown on the bars. ${ }^{*} p<0.01$.

of others on an EA2 construct (R1820Stop) truncated near the end of domain IV (Jouvenceau et al., 2001). In contrast, in a study of another EA2 construct (R1279Stop), in which the construct was expressed from human cRNA, no dominant-negative suppression was reported (Wappl et al., 2002). The reason for this discrepancy is unclear but may involve species or methodological differences.

Our finding that PERK activation is involved in the suppression of $\mathrm{Ca}_{\mathrm{V}} 2.1$ expression by $\mathrm{Ca}_{\mathrm{V}} 2.1-\mathrm{P} 1217 \mathrm{fs}$ suggests that the UPR pathway may be involved in the cerebellar dysfunction seen in EA2. The symptoms of EA2 are exacerbated by physiological stresses including fever (Subramony et al., 2003), and it is tempting to speculate that this might synergize with the effect of truncated channels in terms of cellular stress. This would provide a gain-of-function mechanism as to why this disease is dominant
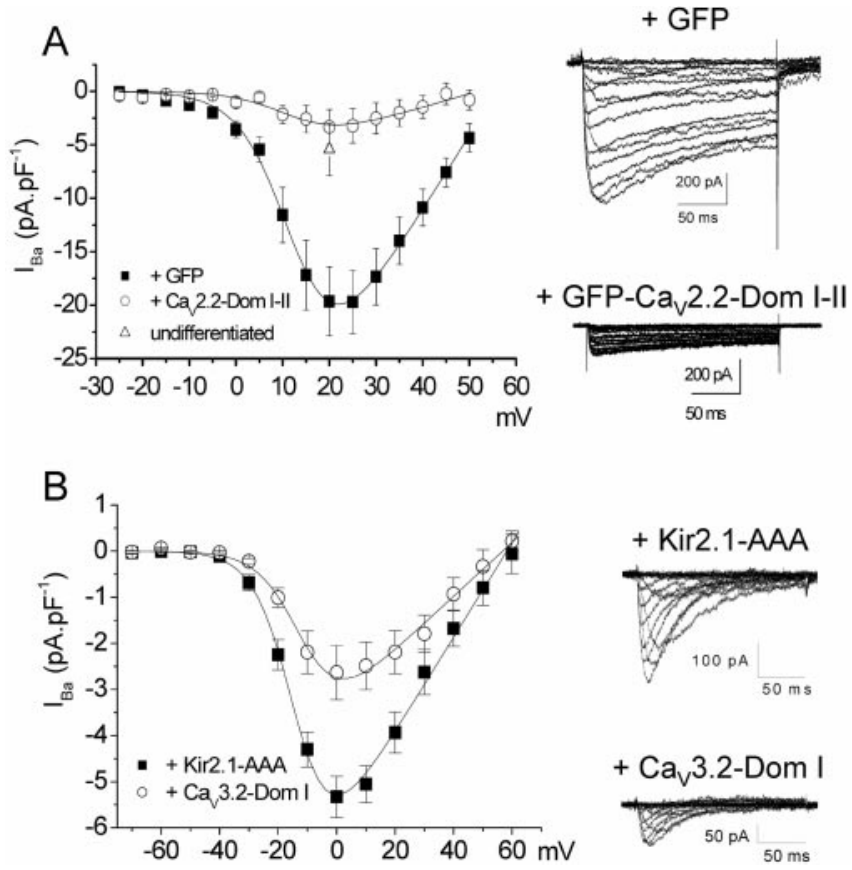

Figure 7. The effect of truncated constructs of $\mathrm{Ca}_{\mathrm{v}} 2.2$ and $\mathrm{Ca}_{\mathrm{v}} 3.2$ on native HVA and T-type currents. $A, I_{\mathrm{Ba}}$ recorded from differentiated $P C 12$ cells. Left, Mean $I-V$ plot for endogenous $I_{\mathrm{Ba}}$ in cells transfected with GFP $(\boldsymbol{\square} ; n=12)$ or GFP-Ca $2.2-D o m ~ I-I I ~(O ; n=15)$. A single point at $+20 \mathrm{mV}$ indicates the peak current amplitude in nontransfected undifferentiated cells $(\triangle ; n=$ 14). Right, Representative current traces from -25 to $+55 \mathrm{mV}$, in $5 \mathrm{mV}$ intervals, for the two conditions; top, GFP transfected; bottom, GFP-Ca $2.2-$ Dom I-IIt transfected. Ba ${ }^{2+}$ was $20 \mathrm{~mm}$. B, $\mathrm{I}_{B \mathrm{a}}$ recorded from undifferentiated NG108-15 cells. Left, Mean I-V plot for T-type currents in

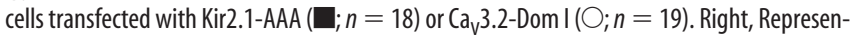
tative current traces from -70 to $+60 \mathrm{mV}$, in $10 \mathrm{mV}$ intervals, for the two conditions; top, Kir2.1-AAA transfected; bottom, Ca $3.2-$ Dom I transfected. Ba ${ }^{2+}$ was $20 \mathrm{~mm}$.

and episodic, rather than being attributed solely to haploinsufficiency. However, it is likely that nonsense-mediated mRNA decay (Dreyfuss et al., 2002) limits the amount of truncated $\mathrm{Ca}_{\mathrm{V}} 2.1$ proteins expressed to an extent depending on the specific mutation. This would mitigate the neurotoxic effects of the truncated channel and provide a basis for the variable phenotype of disease. Our findings may also help explain the discrepancy between the lack of any reduction in P/Q-type currents in the cerebellar granule cells of heterozygotes of $\mathrm{C}_{\mathrm{V}} 2.1$ knock-out mouse disrupted early in domain I (Jun et al., 1999), whereas in a mouse in which the disruption of $\mathrm{Ca}_{\mathrm{V}} 2.1$ was within domain II, allowing the possibility of truncated protein production, the calcium currents in heterozygotes were $\sim 50 \%$ of normal (Fletcher et al., 2001).

It is possible that UPR pathways are also involved in other human and mouse calcium channelopathies showing cerebellar degeneration. The lack of $\beta 4$ in the lethargic mouse (Burgess et al., 1997), might lead to accumulation of immature $\alpha 1$ subunits in the ER of Purkinje neurons, in which $\beta 4$ is the predominant $\beta$ subunit, potentially leading to chronic ER stress. Similarly, the ducky mouse has a mutation resulting in a truncated product of $\alpha 2 \delta$-2 in Purkinje neurons (Brodbeck et al., 2002).

Voltage-gated channels represent a class of difficult-to-fold membrane proteins because of their size, the presence of a pore, and charged residues in their TM segments. In the case of HVA calcium channels, this is compounded by the need to associate with auxiliary subunits to enable maturation and trafficking out of the ER. In one study, a domain responsible for the low expression of $\mathrm{Ca}_{\mathrm{V}} 2.1$ was identified (Hans et al., 1999). In the present 
study, $\mathrm{Ca}_{\mathrm{V}} 2.1$ expression was more markedly inhibited by $\mathrm{Ca}_{\mathrm{V}} 2.1-\mathrm{P} 1217 \mathrm{fs}(>90 \%)$ than was $\mathrm{Ca}_{\mathrm{V}} 2.2$ by its cognate twodomain construct (Raghib et al., 2001). Thus, $\mathrm{Ca}_{\mathrm{V}} 2.1$ may be particularly prone to mutations and conditions affecting its folding and assembly. It will be of great interest to examine the generality of this hypothesis in the future.

\section{References}

Ahern CA, Arikkath J, Vallejo P, Gurnett CA, Powers PA, Campbell KP, Coronado R (2001) Intramembrane charge movements and excitationcontraction coupling expressed by two-domain fragments of the Ca2+ channel. Proc Natl Acad Sci USA 98:6935-6940.

Arikkath J, Felix R, Ahern C, Chen CC, Mori Y, Song I, Shin HS, Coronado R, Campbell KP (2002) Molecular characterization of a two-domain form of the neuronal voltage-gated P/Q-type calcium channel $\alpha_{1} 2.1$ subunit. FEBS Lett 532:300-308.

Barclay J, Balaguero N, Mione M, Ackerman SL, Letts VA, Brodbeck J, Canti C, Meir A, Page KM, Kusumi K, PerezReyes E, Lander ES, Frankel WN, Gardiner RM, Dolphin AC, Rees M (2001) Ducky mouse phenotype of epilepsy and ataxia is associated with mutations in the Cacna2d2 gene and decreased calcium channel current in cerebellar Purkinje cells. J Neurosci 21:6095-6104.

Brodbeck J, Davies A, Courtney J-M, Meir A, Balaguero N, Canti C, Moss FJ, Page KM, Pratt WS, Hunt SP, Barclay J, Rees M, Dolphin AC (2002) The ducky mutation in Cacna2d 2 results in altered Purkinje cell morphology and is associated with the expression of a truncated $a 2 d-2$ protein with abnormal function. J Biol Chem 277:7684-7693.

Burgess DL, Jones JM, Meisler MH, Noebels JL (1997) Mutation of the $\mathrm{Ca} 2+$ channel beta subunit gene Cchb4 is associated with ataxia and seizures in the lethargic (lh) mouse. Cell 88:385-392.

Campbell V, Berrow N, Brickley K, Page K, Wade R, Dolphin AC (1995) Voltage-dependent calcium channel $\beta$-subunits in combination with alphal subunits have a GTPase activating effect to promote hydrolysis of GTP by $\mathrm{G}$ alpha $\mathrm{o}_{\mathrm{o}}$ in rat frontal cortex. FEBS Lett 370:135-140.

Canti C, Page KM, Stephens GJ, Dolphin AC (1999) Identification of residues in the N-terminus of $\alpha 1 \mathrm{~B}$ critical for inhibition of the voltagedependent calcium channel by G $\beta \gamma$. J Neurosci 19:6855-6864.

Canti C, Davies A, Berrow NS, Butcher AJ, Page KM, Dolphin AC (2001) Evidence for two concentration-dependent processes for $\beta$ subunit effects on $\alpha 1 \mathrm{~B}$ calcium channels. Biophys J 81:1439-1451.

Catterall WA (2000) Structure and regulation of voltage-gated $\mathrm{Ca}^{2+}$ channels. Annu Rev Cell Dev Biol 16:521-555.

Chemin J, Nargeot J, Lory P (2002) Neuronal T-type $\alpha 1 \mathrm{H}$ calcium channels induce neuritogenesis and expression of high-voltage-activated calcium channels in the NG108-15 cell line. J Neurosci 22:6856-6862.

Cormack BP, Valdivia RH, Falkow S (1996) FACS-optimized mutants of the green fluorescent protein (GFP). Gene 173:33-38.

Denier C, Ducros A, Vahedi K, Joutel A, Thierry P, Ritz A, Castelnovo G, Deonna T, Gerard P, Devoize JL, Gayou A, Perrouty B, Soisson T, Autret A, Warter JM, Vighetto A, Van Bogaert P, Alamowitch S, Roullet E, Tournier-Lasserve E (1999) High prevalence of CACNA1A truncations and broader clinical spectrum in episodic ataxia type 2. Neurology 52:1816-1821.

Dreyfuss G, Kim VN, Kataoka N (2002) Messenger-RNA-binding proteins and the messages they carry. Nat Rev Mol Cell Biol 3:195-205.

Ertel EA, Campbell KP, Harpold MM, Hofmann F, Mori Y, Perez-Reyes E, Schwartz A, Snutch TP, Tanabe T, Birnbaumer L, Tsien RW, Catterall WA (2000) Nomenclature of voltage-gated calcium channels. Neuron 25:533-535.

Fletcher CF, Tottene A, Lennon VA, Wilson SM, Dubel SJ, Paylor R, Hosford DA, Tessarollo L, McEnery MW, Pietrobon D, Copeland NG, Jenkins NA (2001) Dystonia and cerebellar atrophy in Cacnala null mice lacking P/Q calcium channel activity. FASEB J 15:1288-1290.

Hans M, Urrutia A, Deal C, Brust PF, Stauderman K, Ellis SB, Harpold MM, Johnson EC, Williams ME (1999) Structural elements in domain IV that influence biophysical and pharmacological properties of human $\alpha_{1 \mathrm{~A}^{-}}$ containing high-voltage-activated calcium channels. Biophys J 76:1384-1400.

Harding HP, Zhang Y, Ron D (1999) Protein translation and folding are coupled by an endoplasmic-reticulum- resident kinase. Nature 397:271-274.

Harding HP, Zhang YH, Bertolotti A, Zeng HQ, Ron D (2000) Perk is essential for translational regulation and cell survival during the unfolded protein response. Mol Cell 5:897-904.

Harding HP, Calfon M, Urano F, Novoa I, Ron D (2002) Transcriptional and translational control in the Mammalian unfolded protein response. Annu Rev Cell Dev Biol 18:575-599.

Horwich A (2002) Protein aggregation in disease: a role for folding intermediates forming specific multimeric interactions. J Clin Invest 110:1221-1232.

Imai Y, Soda M, Inoue H, Hattori N, Mizuno Y, Takahashi R (2001) An unfolded putative transmembrane polypeptide, which can lead to endoplasmic reticulum stress, is a substrate of Parkin. Cell 105:891-902.

Jouvenceau A, Eunson LH, Spauschus A, Ramesh V, Zuberi SM, Kullmann DM, Hanna MG (2001) Human epilepsy associated with dysfunction of the brain P/Q-type calcium channel. Lancet 358:801-807.

Jun K, Piedras-Renteria ES, Smith SM, Wheeler DB, Lee SB, Lee TG, Chin HM, Adams ME, Scheller RH, Tsien RW, Shin HS (1999) Ablation of $\mathrm{P} / \mathrm{Q}$-type Ca2 + channel currents, altered synaptic transmission, and progressive ataxia in mice lacking the alpha $(1 \mathrm{~A})$-subunit. Proc Natl Acad Sci USA 96:15245-15250.

Liu CY, Kaufman RJ (2003) The unfolded protein response. J Cell Sci 116:1861-1862.

Mazumder B, Seshadri V, Fox P (2003) Translational control by the 3'UTR: the ends specify the means. Trends Biochem Sci 28:91-98.

Meir A, Bell DC, Stephens GJ, Page KM, Dolphin AC (2000) Calcium channel $\beta$ subunit promotes voltage-dependent modulation of $\alpha 1 \mathrm{~B}$ by $\mathrm{G} \beta \gamma$. Biophys J 79:731-746.

Mori K (2000) Tripartite management of unfolded proteins in the endoplasmic reticulum. Cell 101:451-454.

Moss FJ, Viard P, Davies A, Bertaso F, Page KM, Graham A, Canti C, Plumpton M, Plumpton M, Clare JJ, Dolphin AC (2002) The novel product of a five-exon stargazin-related gene abolishes $\mathrm{Ca}_{\mathrm{V}} 2.2$ calcium channel expression. EMBO J 21:1514-1523.

Okagaki R, Izumi H, Okada T, Nagahora H, Nakajo K, Okamura Y (2001) The maternal transcript for truncated voltage-dependent $\mathrm{Ca}^{2+}$ channels in the ascidian embryo: a potential suppressive role in $\mathrm{Ca}^{2+}$ channel expression. Dev Biol 230:258-277.

Ophoff RA, Terwindt GM, Vergouwe MN, van Eijk R, Oefner PJ, Hoffman SM, Lamerdin JE, Mohrenweiser HW, Bulman DE, Ferrari M, Haan J, Lindhout D, van Ommen GJ, Hofker MH, Ferrari MD, Frants RR (1996) Familial hemiplegic migraine and episodic ataxia type-2 are caused by mutations in the $\mathrm{Ca}^{2+}$ channel gene CACNL1A4. Cell 87:543-552.

Pestova TV, Kolupaeva VG, Lomakin IB, Pilipenko EV, Shatsky IN, Agol VI, Hellen CU (2001) Molecular mechanisms of translation initiation in eukaryotes. Proc Natl Acad Sci USA 98:7029-7036.

Pfaffl MW, Horgan GW, Dempfle L (2002) Relative expression software tool (REST) for group-wise comparison and statistical analysis of relative expression results in real-time PCR. Nucleic Acids Res 30:e36.

Plummer NW, McBurney MW, Meisler MH (1997) Alternative splicing of the sodium channel SCN8A predicts a truncated two-domain protein in fetal brain and non-neuronal cells. J Biol Chem 272:24008-24015.

Raghib A, Bertaso F, Davies A, Page KM, Meir A, Bogdanov Y, Dolphin AC (2001) Dominant-negative synthesis suppression of voltage-gated calcium channel $\mathrm{Ca}_{\mathrm{v}} 2.2$ induced by truncated constructs. J Neurosci 21:8495-8504.

Robbins J, Marsh SJ, Brown DA (1993) On the mechanism of M-current inhibition by muscarinic $\mathrm{m} 1$ receptors in DNA-transfected rodent neuroblastoma x glioma cells. J Physiol (Lond) 469:153-178.

Ron D (2002) Translational control in the endoplasmic reticulum stress response. J Clin Invest 110:1383-1388.

Rutkowski DT, Kaufman RJ (2004) A trip to the ER: coping with stress. Trends Cell Biol 14:20-28.

Ryu EJ, Harding HP, Angelastro JM, Vitolo OV, Ron D, Greene LA (2002) Endoplasmic reticulum stress and the unfolded protein response in cellular models of Parkinson's disease. J Neurosci 22:10690-10698.

Sachs AB, Varani G (2000) Eukaryotic translation initiation: there are (at least) two sides to every story. Nat Struct Biol 7:356-361. 
Schorge S, Gupta S, Lin ZX, McEnery MW, Lipscombe D (1999) Calcium channel activation stabilizes a neuronal calcium channel mRNA. Nat Neurosci 2:785-790.

Subramony SH, Schott K, Raike RS, Callahan J, Langford LR, Christova PS, Anderson JH, Gomez CM (2003) Novel CACNA1A mutation causes febrile episodic ataxia with interictal cerebellar deficits. Ann Neurol 54:725-731.

Tinker A, Jan YN, Jan LY (1996) Regions responsible for assembly of inwardly rectifying potassium channels. Cell 87:857-868.

Tomlinson WJ, Stea A, Bourinet E, Charnet P, Nargeot J, Snutch TP (1993) Functional properties of a neuronal class C L-type calcium channel. Neuropharmacology 32:1117-1126.
Usowicz MM, Porzig H, Becker C, Reuter H (1990) Differential expression by nerve growth factor of two types of $\mathrm{Ca} 2+$ channels in rat phaeochromocytoma cell lines. J Physiol (Lond) 426:95-116.

Wappl E, Koschak A, Poteser M, Sinnegger MJ, Walter D, Eberhart A, Groschner K, Glossmann H, Kraus RL, Grabner M, Striessnig J (2002) Functional consequences of $\mathrm{P} / \mathrm{Q}$-type $\mathrm{Ca} 2+$ channel Cav2.1 missense mutations associated with episodic ataxia type 2 and progressive ataxia. J Biol Chem 277:6960-6966.

Wielowieyski PA, Wigle JT, Salih M, Hum P, Tuana BS (2001) Alternative splicing in the intracellular loop connecting domains II and III of the $\alpha_{1}$ subunit of $\mathrm{Ca}_{\mathrm{v}} 1.2 \mathrm{Ca}^{2+}$ channels predicts two-domain polypeptides with unique C-terminal tails. J Biol Chem 276:1398-1406. 